\title{
ACADEMIC STAFF DEVELOPMENT PROGRAMME TO ENHANCE RESEARCH COMPETENCE: A CASE STUDY
}

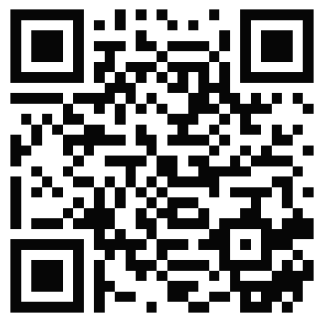

To cite this article:
Svitlana Sysoieva, Dr. Sc., Prof.

Academician-Secretary,

Department of General Pedagogy and Philosophy of Education,

National Academy of Educational Sciences of Ukraine,

Kyiv, Ukraine

2099823@gmail.com

https://orcid.org/0000-0003-2499-732X

\section{Iryna Sokolova, Dr. Sc., Prof.}

Professor, Higher Education,

Health and Hygiene Management Department,

Donetsk National Medical University,

Mariupol, Ukraine

i.v.sokolova1808@gmail.com

https://orcid.org/0000-0003-4425-1859

Sysoieva, S. \& Sokolova, I. (2020). Academic staff development programme to enhance research competence: a case study.

Education: Modern Discourses, 3, 78-87.

https://doi.org/10.37472/2617-3107-2020-3-07

\begin{abstract}
Findings from this study include a summary of best practices in terms of Academic staff development programme (ASDP) to support the implementation of the Research modules to enhance the university teacher's research competence. Mixed methods (qualitative and quantitative) approach and the case study were used to explore the problem, to find out the result of Research modules implementing into the practical space where university teachers had the opportunity to engage in active training. The authors highlighted general principles of active/ research-based learning in practical space training environments, focused specifically on the content of Research modules for lectures - Early-Stage Researchers, Doctoral candidates (Gr. A, the RM I); for PhD holders, professors, doctoral degree holders (Gr. B, the RM II). The teaching and learning strategies used in the modules were a combination of workshops, case studies, small group discussions, pair peer review and independent study including a literature review of relevant research. The research has shown that competency enhancement programme with Research modules is effective and crucial for developing Academic staff research competence at universities. The evaluation of competence research components has revealed the positive changes and confirmed the effectiveness of the Research modules. The programs of the Modules have effectively contributed to the development of Academic staff research competence. The proposed ASDP can be applied to other universities. Some recommendations for Academic staff developers, Curriculum development managers, coaches are suggested for consideration and using to support the professional development of academic and research staff.
\end{abstract}

Key words: academic staff development programme; a case study; Research module; research knowledge; research skills; research competence. 


\section{INTRODUCTION. RELEVANCE}

National Strategy of Ukraine for scientific-research activity is harmonized with the objectives of two main documents - Laws of Ukraine "On Higher Education" (2014) and "On Science and Scientific and Technology Activities" (2015). To implement the Law of Ukraine "On Higher Education", harmonized with "Standards and Guidelines for Quality Assurance (QA) in the EHEA" (Standards and Guidelines, 2015), Ukrainian HEIs are involved in QA processes in various ways, focused on learning, teaching and research output.

The key task of Ukrainian University science system reforming, outlined by the law "On Science and Scientific and Technology Activities", is to change the approach to research and innovations, publishing or implementation of their results, to achieve the quality of scientific content, harmonize them with global scientific achievements and ensure their competitiveness (Ministry of Education and Science of Ukraine, 2017, p. 13).

At the present time when the importance of competence-based approach is increasingly emphasized in educational sciences, our attention has been drawn to the research competence phenomenon.

\section{THEORETICAL ASSUMPTIONS OF RESEARCH}

Research competency of the university teacher is defined as an integral, integrative property of a person combining knowledge, skills, scientific experience, personal values and qualities of a researcher; the proven ability to carry out research activities, to organize students' productive research work (Bondarenko, 2015, p. 10); a characteristic of the personality, indicating the formation of skills and methods of research to find knowledge and solve educational problems (Arkhipova, 2010); a personal quality, a multicomponent, which is formed on the basis of knowledge, skills, values (Yaroshenko, 2019, p. 9-10).

The Researcher Development Framework (RDF, the UK), as a major new approach to researcher development, includes four domains - so-called the portfolio of knowledge, intellectual abilities, skills, techniques and professional standards to do research (Researcher Development Framework, 2011). Domain A contains the knowledge base (Subject knowledge, Theoretical knowledge, Practical application, Information seeking, Information literacy and management, Languages, Academic literacy, and numeracy) and intellectual abilities (Cognitive Creativity) needed to be able to carry out excellent research. Domain B contains the personal qualities, career and self-management skills, required to take ownership and control of professional development; Domain $\mathrm{C}$ - the knowledge of the standards, requirements and professional conduct that are needed for the effective management of research. The knowledge, understanding, and skills needed to engage with, influence and impact on the academic, social, cultural and economic context were organized in Domain D (Researcher Development Framework, 2011).

We focused on Ukrainian scholars, whose academic writings deserve recognition in the European Research Area (Sysoieva \& Kozak, 2016; Yaroshenko, 2018). In a study by Srivastava, the idea of organizational ethos systems in exploring the new potentialities for research competence within the universities is introduced. The research competence of academic staff is associated with the capacity and willingness to find the meaning solution of the novel problems through intellectual skills and knowledge: is the most important factor to gain the research funding, needful consultancy and opportunity to recruit the competent students for sustainable output (Srivastava, 2017, p. 79).The author explored the advantages and challenges of organizational ethos in relation to research competence among universities (Srivastava, 2017). 
The problems of Academic and pedagogical staff research competence formation in HEIs are analyzed on a fragmented basis (Bondarenko, 2015; Golovan \& Yatsenko, 2012; Nozhko, 2018), mainly focusing on Ph.D. holders research competence (Kozubtsov, 2015; Nikolaieva, Koval, 2019). Cognitive, research and value components have been distinguished by Yaroshenko in the structure of an academic's research competence (Yaroshenko, 2019, p. 9-10).

The problem of research competence development of academic staff, trained in special programme (Research modules), is not available for in-depth studies.

The aim of the study: to evaluate the efficiency of the Academic staff development programme (ASDP, Research modules) to enhance the university teacher's research competence. This research was guided by the following research questions:

1. What is the effect of ASDP (Research modules) on the research competence of different groups of university teachers?

2. What recommendations can be made to improve Academic staff research competence development practice?

\section{METHODOLOGY}

Our study is based on a conceptual framework of academic staff research competence enhancing.

Research competence is seen in our article as an integrated personal and professional quality of a higher education teacher, which reflects the motivation for scientific research, the level of teaching research methodology, the personal qualities of a researcher, such as innovative thinking, the capacity for creativity and innovation.

We have identified the following key components of the Research competence of a higher education teacher: motivational and valuable, cognitive, procedural and active, information, communicative, personal and creative, reflexive (Sysoieva \& Kozak, 2016, p. 46-47). Evidently, mentioned above components result in research-oriented behavior of a higher education teacher at each stage of his/her continuous professional development, so they are "measurable person's characteristic" (Bertoncelj, 2010).

The research competency model for Academic staff describes the critical behaviors associated with success in research and depicts the underlying knowledge, skills, abilities, and characteristics associated with good research performance.

As a theoretical assumption the hypothesis was put forward in our study: components of research competence form a holistic unity of the results of academic staff professional and personal development; while learning Research modules university teachers could assess the current level of their research knowledge and skills and take responsibility for their continued professional development.

We focused on Case study research to explore the problem in more depth. Considering Case study elements and descriptors (Harrison, et. al., 2017) and common approaches to case study research (Kumar, 2019; Yin, 2014) we concluded, that Case study research was the most suitable for a holistic, and in-depth investigation of phenomena (research competence) and RMs implementation to enhance Academic staff research competence. We agreed with Yin (2014), that a Case study is a qualitative approach in which the investigator explores a bounded system over time through detailed, in-depth data collection involving multiple sources of information and reports a case description.

According to a Case study design we determined the object of the case study (academic staff development programme to enhance research competence); set out the bounds for the case by time and place. As the context is significant to understand the case, contextual variables (include cultural, and organizational factors) were also taken into account. 
The study was conducted at the University environment because one of its cardinal roles is to oversee teacher education, training and development programmes. We consider the institutional research culture to be the most significant for teaching quality assurance. Academic staff development programme with RMs have been established at two Ukrainian Universities: Borys Grinchenko Kyiv University (full programme with Research modules) \& Mariupol State University (the expertise) during 2015-2017.

In order to gain an understanding of the research questions of this study a mixed research methods design was used. To diagnose the Academic staff research competence a series of diagnostic methods, that allow subtle evaluation of some components, were used (Table 1).

Table 1

Diagnostic methods for evaluation research competence

\begin{tabular}{|l|l|}
\hline $\begin{array}{c}\text { Competence research } \\
\text { components (criteria) }\end{array}$ & \multicolumn{1}{c|}{ Diagnostic methods } \\
\hline Cognitive & Self-assessment method of theoretical readiness for research activity \\
\hline Procedural and active & Self-assessment method of practical readiness to conduct a research \\
\hline Information & $\begin{array}{l}\text { Self-assessment method of readiness to work with information and database, } \\
\text { using different tools }\end{array}$ \\
\hline Reflexive & Essay "My research competence" \\
\hline
\end{tabular}

The ASDP Research modules (as the product of the study) were validated by experts; results were used as a guide to improving the content, programme design and assessment.

\section{CASE PRESENTATION}

In this part of the article, we present the case to illustrate the introduction of the RMs to enhance the university teacher's research competence, as well as advantages peculiarities of applying RMs in the Ukrainian university.

Borys Grinchenko Kyiv University (BGKU) is a student-centered, research-intensive and globally involved university of over 140-year history. Over 8 thousand students do courses in 45 majors (The University, 2020). The high professional level of teaching provided Academic Staff: 743 persons (in general), among them $359 \mathrm{PhDs}$ and 92 Doctors of sciences. Long-term educational traditions and philosophy of servant leadership ensure the personal development of students and staff (BGKU, Statistics, 2019).

The corporate culture of the University is based on the philosophy of servant-leadership that professes human development and building of human relationships as the most important social values. The core values are person, community, trust, spirituality, servant-leadership, responsibility, professionalism, civic identity, freedom, diversity. BGKU is a member of the International Association of Universities (2012), the European University Association (2013) and the European Health and Fitness Association (2015). Looking for new academic opportunities, learning from international experience provides staff and students with great opportunities for professional growth.

Academic staff is defined in Ukraine as academic professionals who are responsible for planning, directing and undertaking academic teaching and research within higher education providers (HEIs). At the doctoral level, Ukraine has a two-degree system, the first qualification is the Candidate of Sciences (Ph.D. degree), and the second one is the Doctor of Sciences (DSc).

The study included 148 university teachers from Borys Grinchenko Kyiv University (groups A, B, N=137, full programme) and Mariupol State University (partially group C, $\mathrm{N}=11$ ) during 2015-2017. The participants from group C (professors) were asked to participate as content validation experts. 
In terms of gender distribution, the majority (89\%) were female; while $11 \%$ were male. The mean age of the participants in Gr. A was 28, 5 years, in Gr. B - 39, 5 years. Participants' ages in Gr. C ranged from 48 to 61 years with $100 \%$ identified as female.

In terms of teaching staff's highest academic qualification, in Gr. A majority (72\%) held a master's degree, followed by 23 Ph.D. students (28\%), respectively. The majority of teaching staff are at the rank of Lecturer (52,5\%) and Senior lecturer (47,5\%). The academic staff's length of university service was up to 5 years.

As for Gr. B the majority $(78,2 \%)$ held a Ph.D. degree, followed by doctoral candidates $(21,8 \%)$, respectively. The academic staff's length of university service was up to 16 years. The majority of teaching staff are at the rank of Senior lecturer $(58,2 \%)$ and Associate professor $(34,5 \%)$, followed by Lecturer $(7,3 \%)$.

The doctoral degree is the highest level of award in the Ukrainian higher education system. All the participants in Gr. C held a doctoral degree (Doctors of sciences). The academic staff's length of university service was more than 20 years. Thus, it is reasonable to infer that most of the staff involved in the study had sufficient experience and knowledge to expertise ASDP (Research modules).

To meet the aim of the study ASDP (Research modules) were designed to be put into practice at BGKU. All newly appointed university teachers (up to 5 years of university service) need to prove basic pedagogical competences, including research competence. Academics were expected to engage in continuous professional development and critical self-reflection throughout their research careers.

The programme of each Research module covered all relevant aspects of academic staff research activities but differed in objectives, content, learning outcomes and results of mastering the program (sufficient or creative level of research competence development).

The Research module I for lectures - Early-Stage Researchers, Doctoral candidates (Group A, N = 82) - was aimed at acquiring the set of knowledge and concepts that made up a professional domain: the methodology of scientific and pedagogical research, the role of tools and methods of research and in practice of planning, conducting of research projects. The lectures needed to be familiar with the main theoretical and methodological approaches in humanities and social sciences. Three content clusters were provided to the program participants: "Methodology of scientific research", "Processing and designing of pedagogical research results", "Academic staff activity on students' research competencies formation".

The main learning outcomes were properly defined in terms of knowledge, skills (to work with scientific sources, information systems, to interpret data and present results of research projects to formulate and present the results of scientific research etc.) and abilities of critical thinking in reception and interpretation of the data from research; supporting research activities of students. Upon completion of the research module, participants had to prepare the required paperwork for a real research project.

The Research module II (Group B, N =55) was designed for Ph.D. holders, who wanted to pursue a doctorate degree (DSc), for professors and doctoral degree holders. It was aimed at the acquisition of the highest research competence in the Education Sciences.

The module provided a thorough overview of the following topics:

- Research training in Education Sciences: a methodology of scientific research programmes; subject-matter knowledge in the chosen education research theme; methodological knowledge and skills; academic staff career development.

- Ph.D. training programmes in EU countries, the USA, in Ukraine: Course and Curricular Requirements; postgraduate research course context; research supervision.

- Research level of higher education in Ukraine. DSC Training Programme. Scientific and Educational Trends and Schools. 
The training was carried out in accordance with the main principles of andragogy; adult learner professional experience and personal qualities were taken into account: the priority of personalized, individualized and independent learning; joint productive activity, maximizing the effectiveness of learning. Since higher education teachers (adults) are self-directed, the content was focused on issues related to their professional activity to meet their educational needs, be relevant, to help them in achieving learning outcomes.

The teaching and learning strategies used in the module were a combination of workshops, case studies, small group discussions, pair peer review and independent study including a literature review of relevant research. Workshops supported the core modules and focused on specific practical skills required by Academic staff to conduct scientific researches effectively. University teachers practiced the skills required to present the research findings of others, facilitated a research-oriented discussion, and were engaged in open debates.

The empirical data, which we acquired during the first phase (1 Ph.), were used to compare after the activity phase $(2 \mathrm{Ph}$.) of the experiment. The control phase of the study consisted of rediagnostics in the same complex of techniques (except the essay "My research competence", the questionnaire survey "Module content expertise") in order to measure research competence formation.

\section{FINDINGS. DISCUSSIONS}

Only part of the research competence components for each group are analyzed here.

Diagnostics of the research competence according to the cognitive, procedural and active, informational and communicative criteria. It is well known, that competence is expressed in performance, but it never reveals a person's entire knowledge and abilities to act. To address research questions the next task of our study was to determine the level of the research competence formation according to the cognitive, procedural and active, informational criteria based on the self-assessment method.

The complex questionnaire consisted of a set of prompts that aimed to collect information from respondents of their theoretical readiness for research activity, to conduct research, to work with information and database, using different tools.

The participants of both groups (Gr. A, B) were asked to fill out three sections of items, listing a set of knowledge areas (section $\mathrm{A}$ ) about the methodology and methods of pedagogical research (the cognitive component). Section B consisted of items, which sought to evaluate procedure activity that reflects the ability of a person to conduct a research cycle. Section $\mathrm{C}$ contained items seeking the informational component of the research competence.

The results were used to diagnose the research competence (some components) and to interpret the efficiency of their formation according to the low, average, above average, high levels. The main findings of the study are presented in Table 2.

Questionnaire results showed the opinion and assessment of survey respondents. The basic features of their responses were analyzed using descriptive statistics.

The low level of research competence in accordance with the cognitive criterion means that the participants from Gr. A (68\%) demonstrated limited theoretical knowledge, showed no connection between his/her knowledge and practical activity before training (1 Ph.). Above-average and high levels of competence mean that the respondents from Gr. B (58\%) had a stable positive motivation for improving knowledge and building skills. A majority of respondents ( $73 \%$ from Gr. A and $18 \%$ from Gr. B) showed a low level of informational competence formation, reporting the difficulties in working with information and database, using modern information technologies. The study also identified gaps in the knowledge and skills of participants to conduct a research cycle, to select and use methods, to derive conclusions and to present findings ( $71 \%$ from Gr. A and $11 \%$ from Gr. B). 


\section{Diagnostic of research competence (Self-assessment method)}

\begin{tabular}{|c|c|c|c|c|c|}
\hline $\begin{array}{c}\text { Groups } \\
(N)\end{array}$ & Phase & $\begin{array}{l}\text { Low level } \\
\text { Number \% }\end{array}$ & $\begin{array}{l}\text { Average level } \\
\text { Number \% }\end{array}$ & $\begin{array}{c}\text { Above-average } \\
\text { level }\end{array}$ & Number \% \\
\hline \multicolumn{6}{|c|}{ Section A. The result of the questionnaire "Cognitive criterion" } \\
\hline \multirow[t]{2}{*}{ Gr. A (82) } & I & $56 \quad 68 \%$ & $22 \quad 27 \%$ & $4 \quad 5 \%$ & - \\
\hline & II & $42 \quad 51 \%$ & $2530 \%$ & $11 \quad 13 \%$ & $45 \%$ \\
\hline \multirow[t]{2}{*}{ Gr. B (55) } & I & $6 \quad 11 \%$ & $17 \quad 31 \%$ & $21 \quad 38 \%$ & $1120 \%$ \\
\hline & II & $4 \quad 7 \%$ & $15 \quad 27 \%$ & $23 \quad 42 \%$ & $1324 \%$ \\
\hline \multicolumn{6}{|c|}{ Section B. The result of the questionnaire "Procedural and active criterion" } \\
\hline \multirow[t]{2}{*}{ Gr. A (82) } & I & $58 \quad 71 \%$ & $2328 \%$ & $11 \%$ & $-\quad-$ \\
\hline & II & $44 \quad 54 \%$ & $2530 \%$ & $11 \quad 13 \%$ & $25 \%$ \\
\hline \multirow[t]{2}{*}{ Gr. B (55) } & I & $6 \quad 11 \%$ & $17 \quad 31 \%$ & $2138 \%$ & $1120 \%$ \\
\hline & II & $47 \%$ & $15 \quad 27 \%$ & $23 \quad 42 \%$ & $1324 \%$ \\
\hline \multicolumn{6}{|c|}{ Section C. The result of the questionnaire "Informational criterion" } \\
\hline \multirow[t]{2}{*}{ Gr. A (82) } & I & $6073 \%$ & $1619 \%$ & $56 \%$ & $11 \%$ \\
\hline & II & $4656 \%$ & $2126 \%$ & $1113 \%$ & $45 \%$ \\
\hline \multirow[t]{2}{*}{ Gr. B (55) } & I & $1018 \%$ & $2036 \%$ & $2138 \%$ & $4 \quad 7 \%$ \\
\hline & II & $59 \%$ & $2240 \%$ & $2240 \%$ & $611 \%$ \\
\hline
\end{tabular}

Three sets of open-ended questions were used after the implementation of the Research modules. The respondents of both groups confirmed the qualitative changes in the levels of the competency formation. They emphasized the increase of cognitive knowledge at above-average and high levels.

In Gr. A the number of the respondents with the low level of the research competence (procedural and active criterion) decreased by 17\%, while there was an increase in the number of people, acquired research methodology skill at above-average and high levels. The dynamics of the increase in the number of respondents from Gr. B who increased the level of research competence development according to the determined criteria proved to be insignificant (on average $4 \%)$.

Diagnostics of research competence according to the Reflexive criterion. Participants of group A were asked to write an explanatory essay titled "My research competence: a reflection on self-development" on the results of studying the Research module I.

Our research results indicated that the respondents were generally satisfied with the conditions for the acquisition of knowledge and skills while participating in RM I. The majority of respondents - 61 (74\%) agreed that it was difficult to combine professional activity as a lecturer and a training program. However, the respondents noted professional atmosphere having dominated during the tutorials, indicated new methods mastering, organization and presentation experience on their research projects.

Here are some episodes of the group essay: "The content of the Research module was informative. Our participation involved active engagement in the discussions about personal responsibility for the development of our research competence. We realized our ambitions to increase interaction, gain personal access to the deeply held knowledge and research practices. 
Through workshops on rethinking interactions with stakeholders, we learned how to evaluate research work more critically. We were actively engaged in modeling small group projects and enhancing team dialogue. We learned how knowledge is analyzed in discourse and criticized in the article. The program of the Module has effectively contributed to the development of our research competence".

The questionnaire survey "Module content expertise" confirmed the previously obtained results concerning the Reflexive criterion. The programms were then sent to 11 researchers from Gr. C for RMs content validation. Each judge was asked to work separately to review the RM content. Interview questions explored: a) the effectiveness of the content for research competence development; b) thoughts about Programme themes to serve particular needs, gain results and reach learning outcomes; c) perceptions of the structure of the programme: consistency of the theory with teaching and research practice.

Procedure for content validation was adapted from those described by Waltz \& Bausell (Yaghmale, 2003, p.26); Wynd, et. al (2003). The experts were then asked to rate each item (a) based on relevance, clarity, simplicity and ambiguity on the four-point scale: 1 - not relevant, 2 - somewhat relevant, 3 - quite relevant, and 4 - very relevant (Wynd, Schmidt, et. al., 2003, p. 510).

Nine experts have identified the effectiveness of the content for research competence development as very relevant, two - as quite relevant. Ten experts considered, that programme themes served particular needs, gain results and reach learning outcomes (very relevant). Nine experts indicated as very relevant the structure of the programme. The current results provide a foundation for improving the RM content and making the necessary changes. The programmes have been approved and recommended for widespread use.

\section{CONCLUSIONS AND RECOMMENDATIONS}

The programmes of Research modules I, II covered all relevant aspects of academic staff research activities but differed in objectives, content, learning outcomes and results of mastering the program. The results of the research showed, that workshops, discussions, modeling small projects and enhancing team dialogue are very productive professional development activities, aimed at Academic staff research competence development. The present investigation has found the value orientations (knowledge \& skills, abilities) to enhance Academic staff research competence. The respondents were aware of the need for constant acquisition of knowledge and skills in the methodology of scientific research being engaged in research practices.

It is concluded that the programs of the Modules have effectively contributed to the development of Academic staff research competence. Findings from the current study indicated the positive results, which were obtained in all the differentiated areas (some components of the Research competence) within the application of criteria and low, average and high levels. The main hypothesis of the study has been confirmed: components of Academic staff research competence can be compared and evaluated at each stage of his/her continuous professional development to achieve learning outcomes of Academic staff development programme. Knowledge and skills affect Academic staff value priorities.

On the basis of the research conclusions, the following recommendations are suggested for consideration and use in higher education institutions: to focus on Academic staff development to create strong identities as professionals and to improve training programmes' content and instructional design; to provide Academic staff with ongoing support as array of different types of assistance (instructional, resources, supervisory support) to develop the university teacher's research competence; informal, collaborative and bottom-up institution-wide initiatives between educators and researchers should be encouraged (such as seminars, meetings, working 
lunches, etc. workshops, case studies, small group discussions, pair peer review and independent study including a literature review of relevant research increase the efficiency of the Research Module programmes focused on learning communities research activities.

The results of Research Modules implementing examined in general, but documenting special dynamics in a more in-depth investigation could yield additional nuances of the dynamics at play. Future investigations of Research Module programmes could broaden the scope of this extended case study to include more participants from different universities. The finding also needs to be granulated into a compact model of academic staff research competency. Future researchers may also examine the factors that support the implementation of The Research Module programme at HEIs to improve quality assurance standards.

\section{REFERENCES}

Arkhypova, M.V. (2010). Model formuvannia doslidnytskoi kompetentnosti maybutnoho inzhenera-pedahoha. [Model of forming future engineer-teacher's research competence]. Visnyk Chernihivskoho derzhavnoho pedahohichnoho universytetu. Seriya: Pedahohichni nauky: sbornyk. Chernihivskyi derzh. ped. un-t im. T. Shevchenka, Ukraine, 76, 93-96. (in Ukrainian)

Bondarenko, L.I. (2015). Formuvannya doslidnitskoyi kompetentnosti maybutnih vikladachiv vishchih navchalnih zakladiv $v$ umovah magistraturi [Formation of research competence of teachers of higher educational institutions in Master's degree programme]. (Extended abstract of Ph.D. thesis). Starobilsk: Luganskiy natsionalniy universitet im. Tarasa Shevchenka, Ukraine. (in Ukrainian)

Golovan, M.S., \& Yatsenko, V.V. (2012). Sutnistta zmist ponyattya "doslidnyczka kompetentnist". [Essence and maintenance of concept "research competence"]. Teoriya ta metodyka navchannya fundamentalnyx dyscyplin u vyshhij shkoli: zb. nauk. pracz, VII, 55-62. (in Ukrainian)

Golovan, M. S. (2012). Model formuvannya doslidnickoyi kompetentnosti majbutnih fahivciv $\mathrm{u}$ procesi profesijnoyi pidgotovki [Model of formation of research competence of future specialists in the process of vocational training]. Pedagogichni nauki: teoriya, istoriya, innovacijni tehnologiyi, 5 (23), 196-205. (in Ukrainian)

Kozubczov, I. (2015). Teoretyko-metodologichna osnova rozvy tku doslidnyczkoyi kompetentnosti molodyx naukovciv: pedagogichnyj dosvid [Theoretical and methodological basis for the development of young scientists' research competence: pedagogical experience]. Proceedings from Rozvytok doslidnyczkoyi kompetentnosti molodyx naukovciv: materialy I Vseuk. nauk.-prakt. seminaru, Ky'yiv, 27 sichnya 2015 r. / za zag. red. V. O. Radkevych. (pp. 76-81). Kyiv In.-t profesijno-texnichnoyi osvity NAPN Ukrayiny. (in Ukrainian)

Nikolaieva, Sofiia \& Koval, Tamara. (2019). Vykorystannya informacijno-komunikacijny`x texnologij dlya formuvannya naukovo-doslidnyczkoyi kompetentnosti majbutnix doktoriv filosofiyi. [Use of information and communication technologies for research competency formation of future doctors of philosophy]. Informacijni texnologiyii zasoby navchannya, 70 (2), 237-256. (in Ukrainian)

Nozhko, Ihor. (2018). Doslidnyczka kompetentnist yak naukova kategoriya. [Research competence as a category of science]. Visnyk Cherkaskogo universytetu: Pedagogichni nauky, 1, 69-74. (in Ukrainian)

Pro naukovu i naukovo-texnichnu diyal ist: Zakon Ukrayiny [On Science and Scientific and Technology Activities: The Law of Ukraine] (vid 26. 11. 2015 roku № 848-VIII). Retrieved 2020 from: https://zakon.rada.gov.ua/laws/show/848-19\#Text. (in Ukrainian) 
Sysoieva, S. \& Kozak, L. (2016). Doslidnyczka kompetentnist vykladacha vyshhoyi shkoly: programa rozvytku [Research competence of higher education teacher: program of development]. Neperervna profesijna osvita: teoriya i praktyka (seriya: pedagogichni nauky) vypusk, 1-2, 39-44. doi:10.28925/1609-8595.2016(1-2)3944. (in Ukrainian)

Yaroshenko, O. (2018). Vitchyzniani i zarubizhni praktyky rozvytku doslidnytskoi kompetentnosti naukovo-pedahohichnykh pratsivnykiv v umovakh intehratsii vyshchoi osvity i nauky [Domestic and foreign practices of development of research competence of academic and pedagogical workers in the conditions of integration of higher education and science]. Teoretychni osnovy $i$ tekhnolohiia profesiinoho rozvytku naukovopedahohichnykh pratsivnykiv universytetiv $v$ umovakh intehratsii vyshchoi osvity i nauky: preprynt (analitychni materialy). Kyiv: Instytut vyshchoi osvity NAPN Ukrainy, Ch. 2. Retrieved 2020 from: https://ihed.org.ua/publications/

Borys Grinchenko Kyiv University. Retrieved 2020 from: http://partner.kubg.edu.ua/about/ the-university.html. (in Ukrainian)

Bertoncelj, A. (2010). Managers' Competencies Framework: A Study of Conative Component. Economic Research-Ekonomska Istraživanja, 23:4, 91-101. doi: 10.1080/1331677X. 2010.11517435.

Harrison, Helena \& Birks, Melanie \& Franklin, Richard \& Mills, Jane (2017). Case Study Research: Foundations and Methodological Orientations [34 paragraphs]. Forum Qualitative Sozialforschung / Forum: Qualitative Social Research, 18(1), Art. 19. Retrieved 2020 from: http://nbn-resolving.de/urn:nbn:de:0114-fqs1701195

Holkovskaya, I.L. (Ed.). (2017). Profesijno-pedagogichna kompetentnist vyshhogo navchalnogo zakladu: navchalnyj posibnyk [Professional-pedagogical competence of higher education teacher: a textbook]. Vinnitsa, Ukraine: LLC "Nealan LTD”. (in Ukrainian)

Kumar, Ranjit. (2019). Research methodology: A Step-by-Step Guide for Beginners. SAGE Publications Ltd; Fifth edition

Ministry of Education and Science of Ukraine (MESU). (2017). Innovative development of universities and scientific institutions of the MESU. Retrieved 2020 from: https://mon. gov.ua/ua/nauka/nauka/nauka-v-universitetah (in Ukrainian)

Researcher Development Framework. (2011). Careers Research and Advisory Centre (CRAC) Limited. 23. Retrieved from https://www.srhe.ac.uk/downloads/events/11_Hodges.pdf

Standards and Guidelines for Quality Assurance in the European Higher Education Area (ESG). (2015). Brussels, Belgium.

Srivastava, Kiran. (2017). Research competence of University Faculty members in relation to Organisational Ethos. IOSR Journal Of Humanities And Social Science (IOSR-JHSS), 22 (12), 78-81

The Law of Ukraine "On Higher Education". (2014, July, 01).The Verkhovna Rada of Ukraine; Law №1556-VII. Retrieved 2020 from: http://erasmusplus.org.ua/en/higher-educationin-ukraine.html

Wynd, A. Christine \& Schmidt, Bruce \& Schaefer, Michelle Atkins. (2003). Two Quantitative Approaches for Estimating Content Validity. West J Nurs Res., 25 (5), 508-518. doi:10.1177/0193945903252998

Yin, Robert K. (2014). Case study research: Design and methods. Los Angeles, CA: Sage.

Yaghmale, F. (2009). Content validity and its estimation. J Med Educ. 3 (1), 25-27

Yaroshenko, Olga (2019). Research competence component structure of academic and scientific staff. Neperervna profesijna osvita: teoriya i praktyka (seriya: pedagogichni nauky) vypusk, $3(60), 7-12$ 